\title{
External Audit Quality and Value Creation: What Relationship in the Cameroonian Context
}

\author{
Michael Forzeh Fossung1, Dongmo Kana Valery Verges² \\ ${ }^{1}$ Department of Accounting, University of Buea, Buea, Cameroon \\ ${ }^{2}$ Department of Accounting and Finance, University of Dschang, Dschang, Cameroon \\ Email: michael.fossung@ubuea.cm
}

How to cite this paper: Fossung, M. F., \& Verges, D. K. V. (2022). External Audit Quality and Value Creation: What Relationship in the Cameroonian Context. Open Journal of Accounting, 11, 21-41.

https://doi.org/10.4236/ojacct.2022.111002

Received: November 11, 2021

Accepted: December 25, 2021

Published: December 28, 2021

Copyright $\odot 2022$ by author(s) and Scientific Research Publishing Inc. This work is licensed under the Creative Commons Attribution International License (CC BY 4.0).

http://creativecommons.org/licenses/by/4.0/

\begin{abstract}
A financial statement audit is an essential tool for reducing information asymmetry and maintaining an efficient market environment. However, if the audit strives to improve financial performance, there must be credibility and reliability. This research verifies the link between external audit quality and value creation while controlling for other exogenous factors (the size and age of the firm). Given that most research on this relationship has been carried in the context of developed countries and much more on listed companies, this study adopts a new approach to investigate the contribution of external audit in improving the value creation by unlisted companies like Cameroon. The audit quality was captured by the competence and the independence of the auditor. The creation of value is measured by the evolution of turnover and net income. Using the logistic regression analysis on data collected on a sample of 97 public limited companies in Cameroon, it is proved that audit quality has a positive and significant influence on value creation. Belonging to the Big Four, providing services other than external audit and the evolution of audit fees have no significant impact on value creation. As control variables, the company's size does not explain value creation, but the firm's age does. It is recommended that the management hire a competent auditor who respects the steps of the audit process to create more value. Due to the importance of having a high-quality audit, further studies should explore other external audit quality variables such as co-auditing, adherence to the audit timetable, and the time allowed for audit assignments.
\end{abstract}

\section{Keywords}

Value Creation, Audit Quality, Competence, Independence

\section{Introduction}

Since the end of the 20th century, good governance has become a significant is- 
sue for all nations and companies (Chevallier, 2003). The control mechanisms of managers constitute the main ingredients of the analysis of corporate governance. Corporate governance covers "all the organisational mechanisms that have the effect of delimiting the powers and influencing managers' decisions" (Charreaux \& Philippe, 1997: p. 1). According to the agency theory, this delimitation of powers and management decisions creates agency problems and information asymmetry by managers and shareholders (Jensen \& Meckling, 1976), thus encouraging managers to show a very advantageous situation in their financial accounts. This account manipulation makes the credibility and reliability of financial statements questionable. To ensure the reliability of financial and accounting information, an external auditor who is an independent and competent professional is necessary. The external audit is a corporate governance mechanism whose primary mission is to guarantee the reliability, regularity, and sincerity of the financial statements produced by companies. It also helps to reduce the problems of agency and asymmetry of information between managers and shareholders, which are considered major obstacles to the development and sustainability of the company. To fully achieve its mission, however, the external audit must be of high quality. According to De Angelo (1981a), audit quality is defined as the auditor's ability to detect misstatements in the client's financial accounts through his competence and disclose these misstatements through his independence.

According to Poisson (1989), auditing is one of the main tools of the information process. "The auditor judges both the quality of information (financial audit) and performance (operational audit)" (Poisson, 1989: p. 370). The role of auditors should be a pivotal contribution to financial performance to reduce the risks of significant misstatements and ensure the preparation of financial statements is according to rules and regulations (Heil, 2012). When the users speculate lower risks of misstatements, they rely more on the capital markets and this would lower the cost of capital firms (Heil, 2012).

Moreover, studies conducted by Krishnan (2002), Anderson et al. (2004), Charreaux and Philippe (1997), Moore and Ronen (1990) in the European and American contexts have shown that a quality audit mission favours the performance of the company. This may not be the case with sub-Saharan Africa, in general, and Cameroon in particular, where the business environment is marked by increased corruption, misappropriation of public funds, and inequitable distribution of wealth (Belkaoui, 1994; Zafar, 2002). Besides, the financial market does not play a role in the economic sphere and, according to Djongoue (2007), is marked by severe governance crises and numerous company closures. To understand if variables may relate the same in different market and environmental conditions, we pose the following research question: Does the quality of external audit influence value creation? In other words, what determinants audit quality that explains value creation in Cameroonian firms?

To carry out this study, we use the hypothetical-deductive approach. It is an approach that goes from critical analysis of literature to verification of hypo- 
theses, intending to understand better the effect of audit quality concepts on our dependent variable, which is the creation of value.

This article, in addition to this introduction, is organised around four points. The first presents the literature review on the subject. The second presents the methodological approach used in this study, and the third is the study's empirical results. We will end with a conclusion.

\section{Literature Review and Hypotheses Development}

\subsection{External Audit Quality and Value Creation: Theoretical Basis}

\subsubsection{Assessing Audit Quality}

According to De Angelo (1981a), audit quality is defined as the auditor's ability to detect misstatements in the client's financial accounts through competence and disclose these misstatements through his independence.

We note that audit quality, which is our predictor variable measured through the competence and independence of the external auditor, is challenging to observe and quite tricky to assess. The external user cannot access the auditors' working files because they are confidential and protected by professional secrecy. In addition, the audit report is so standardised in its content and wording that it offers a very tiny possibility of differentiation (Manita \& Chemangui, 2007). To circumvent these limitations, researchers in the field use substitutes to evoke a developed quality. Thus, for our study, we have selected specific criteria for competence (membership of the auditor to the "Big Four", compliance with the stages of the audit process, the audit timetable and the time allowed for auditing assignment) and independence (the evolution of fees, joint auditing, mandate duration and provision of other services in addition to the audit of accounts).

\subsubsection{Assessing Value Creation}

Value creation is a theme of growing interest in various fields of management: strategic management, corporate finance, accounting/management control, marketing. On an academic level, this interest is at the origin of numerous research projects. On a practical level, the theme of value creation has become the new credo of the leaders of large companies (Cappelletti \& Khouatra, 2011). The levers of value creation are multiple. Three types of levers of strategic essence are the source of value creation by the company: Strategic levers, which account for the ability of strategic choices of a company to create value from which to generate its performance, and strategic decisions have an impact on the creation of value by giving the company a competitive advantage (Porter, 1980); Financial levers, which allow for an increase in shareholder value, such as share buybacks on the stock market and financial price risk management (Caby \& Hirigoyen, 2001); Corporate governance levers, which refer to the capacity of governance mechanisms (ownership structure, board of directors and audit) to guarantee the company's long-term performance. We do not intend to make an exhaustive study of this; we will focus on only the governance and the creation of value approximated by financial performance. Several indicators have been used in lite- 
rature to measure the value created by companies, and are of several kinds: economic indicators, accounting indicators and stock market indicators: EVA (Economic Value Added) or economic profit, Net Present Value (NPV), Earnings per share (EPS), Accounting rates of return (ROA, ROE), Equity per share (PER, NPBV), Market Value Added (MVA), Total Shareholders Return (TSR), Tobin's $\mathrm{Q}$, change in turnover and change in net income.

\subsection{Contribution of Corporate Governance Theories to the Explanation of Value Creation}

\subsubsection{Agency Theory and Value Creation}

The agency theory has been widely used in literature to investigate the information asymmetry between principals (shareholders) and agents (management). Sarens and AbdolMohhamadi (2007) believe that agency theory assumes that principals and agents act rationally and use contracting to maximise their wealth. A consequence of this is the moral hazard issue. Louise (2005) states that audits serve a fundamental purpose in promoting confidence and reinforcing trust in financial information. As depicted in agency theory, the principal-agent relationship is vital to understanding how the role of an auditor has developed. Principals appoint agents and delegate some decision-making authority to them. In so doing, the principals trust their agents to act in the principals' best interests. However, due to information asymmetry between principals and agents differing motives, principals may lack trust in their agents. They may therefore need to put in place mechanisms, such as audit, to reinforce this trust. Thus, the agency theory is a valid economic theory of accountability, which helps explain the development of audit quality.

In addition, scholars like Jensen and Meckling (1976), Watts and Zimmerman (1986) believe that the demand for external auditing is at the heart of the agency relationship and analyse this recourse to external auditing as a means of limiting the possibilities of accounting manipulation by managers.

\subsubsection{Stakeholder Theory and Value Creation}

Developed in its current form by Freeman (1984), the stakeholder theory aims to refocus its views around the set of actors who influence the firm. He defines stakeholders as "any group or individual who can influence or be affected by achieving the organisation's objectives". Stakeholders, therefore, include all of the company's internal and external partners who have directly or indirectly contributed a specific resource to the achievement of the company's objectives. The relevance of this theory here comes from the fact that once the firm is seen as an organisation influenced by formal and informal institutions, the governance process no longer can ensure total control.

Accordingly, Sundaram and Inkpen (2004) acknowledge that the stakeholder theory attempts to address the group of stakeholders that require management's attention. Many firms have developed and run their businesses in terms highly consistent with stakeholder theory. Firms such as J \& J, eBay, Google, Lincoln Electric, AES, and the companies featured in Built to Last and Good providing 
compelling examples of how managers understand the core insights of stakeholder theory and use them to create outstanding businesses (Collins \& Porras, 1994).

Taking stakeholders into account gives a signal to improve and strengthen disciplinary mechanisms, fostering collaboration of all partners, and creating value.

\subsubsection{Theory of Inspired Trust and Value Creation}

Developed by the Limperg Institute in the Netherlands in 1985, the theory of inspired confidence states that the auditor, as a confidential agent, derives his broad function in society from the need for expert and independent examination and the need for an expert independent judgement supported by the analyses. Thus, accountants and auditors are expected to know and realise that the public continues to expect a low rate of audit failures, which requires that the auditors must plan and perform their audit in a manner that will minimise the risk of undetected material misstatements. The accountant is under a duty to conduct his work to do not betray the confidence he commands (Limperg et al., 1985). The importance of the theory of inspired confidence is that the duties and responsibilities of the auditors are a derivation from the trust that is bestowed by the public on the success of the audit process and the assurance which the opinion of the accountant conveys. Since the trust determines the existence of the process, a betrayal of this trust logically means a termination of the process or function. Carmichael (2004), in discussing the social significance of auditing stated that when the confidence that society has in the effectiveness of the audit process and the audit report is misplaced, the value relevance of that audit is destroyed. Therefore, auditors are expected to maintain reasonable quality assurance especially given that an audit failure is effectively a career-ending event. Auditing assures the owners and management of companies, investors and stakeholders, and financial reporting, corporate governance, and regulations support confidence in the capital markets.

\subsection{Controversial Relationship between External Audit Quality and Value Creation}

\subsubsection{External Auditor Competence and Value Creation}

H1: The external auditor's membership of the "Big Four" network creates more value within the company,

Very few studies have sought to highlight the link between audit quality and value creation. Since performance is an objective to be achieved, Charreaux and Philippe (1997) believe that control mechanisms such as governance or auditing have an inescapable impact on the company's ability to create value. Alvarez (1997), in his work on the relationship between audit and performance in South America, concludes that auditing is a solution that can help reduce the disadvantages of managerial behaviour. However, he insists that it will only be effective if it is of high quality. Hartarska (2005), on the other hand, in her work on 
the impact of external control in microfinance, shows that in Central and Eastern Europe, auditing has no significant influence on financial and social performance and therefore does not appear to be an effective control mechanism. This result corroborated with Djoutsa and Tagne (2013). They tested the link between audit and performance in microfinance and concluded that there is no link between audit and MFI performance. Flint (1988) believes that the auditor must have sufficient knowledge, training, qualification and experience to carry out the assignment. Moore and Ronen (1990) add that an investor can only distinguish between a good and a bad investment if a competent auditor certifies it. Krishnan (2002), highlighting the relationship between the future profitability of the firm and the quality of auditing, thinks that the membership of the auditor in a big firm (big 4) promotes and increases future profitability. De Angelo (1981a) believes that an auditing firm with the most qualified employees is the most likely to produce a quality audit and, therefore, promote its clients' performance. So based on these thoughts, we notice that competence as an indicator of audit quality is likely to improve the firm's ability to create value, hence our hypothesis developed above.

H2: The respect of the steps of the audit process by external auditor contributes significantly and positively to the creation of value in the company;

Mock and Wright (1999) conclude that a company's success depends on the ability of its auditors to meet the firm's control priorities. They add that these controls must take into account the risk areas of a given firm. For Manita and Chemangui (2007), measuring the degree of adaptation of audit work means evaluating whether the techniques and means of control implemented, compliance with regulations, and procedures would make it possible to detect and explain existing dysfunctions in the firm and thus contribute to the firm's success. It is from this thought that our hypothesis emerges.

\subsubsection{External Auditor Independence and Value Creation}

H3: The provision of other services in addition to the audit by the external auditor does not contribute to value creation in the company;

Goldman and Barlev (1974) believe that different sources of pressure lead to different types of conflicts of interest that may cause the auditor to fail to remain independent in making their judgments, thereby degrading the quality of decisions made by the information users. Anderson et al. (2004) show that firms with fully independent auditors have cheaper access to debt financing, significantly increasing the value created. Nevertheless, Krishnan (2002), highlighting the relationship between the future profitability of firms and audit quality, believes that if the auditor is independent, the quality of their disclosures could lead to significant turnarounds and significant turnarounds to high performance. It is based on this Khrisman's thought that we have formulated this hypothesis.

H4: The evolution of audit fees contributes to the creation of value within the company; 
There is an integral part of literature that is devoted to understanding the issue regarding audit pricing. In the 1980s, Simunic established a demonstrative model of the process in which the fees paid for audit services are specified. From that time, several scholars have persistently carried out forth observed outcomes that display the factors corresponding to the proper apportionment of the audit fees (Moutinho et al., 2012). Hypothetically, the amount paid by the client for audit services to the audit firm reflects the exertion applied to accomplish the auditing circle. Stanley (2011) examines the relationship between profitability and observed auditor remuneration using data collected from US public listed company engagements for seven years. The result displays a transposed link between the audit fee and clients' working performance while audit quality is jeopardised in the long run. An increase in the amount paid as audit fees implies that the auditors offer more professional auditing services to the clients against paying a lower amount for audit fees. However, several studies employ audit fees as the proxy for measuring audit quality because the quality in audit is invisible (Bliss, Gul, \& Majid, 2011). Finally, this study suggestion; this study employs audit fee as one of the bases for the measurement of audit quality, especially an auditor's independence, and this is consistent with the research carried out by (Bliss et al., 2011; Hassan \& Farouk, 2014; Moutinho et al., 2012; Mustapha, Mohd Rashid, Lateef, \& Bala, 2019; Stanley, 2011).

\subsection{Control Variables}

In addition to the audit quality variables, other exogenous factors are likely to influence value creation. They must be taken into consideration to not bias the model of our research and contribute to improving the explanatory power of the latter. These are the size and age of the audited company.

\subsubsection{The Size of the Company and Value Creation}

A review of previous studies shows that the size of the audited firm is the primary variable explaining the choice of auditor and auditor remuneration. Large companies are likely to be audited more efficiently by large international firms due to the human and financial resources at their disposal. Consequently, they will pay significant fees for the work and investigations performed to contribute to value creation. Thus, there is likely to be a positive relationship between firm size and value creation in our context in line with the results obtained by Beasley and Petroni (2001) and Carcello et al. (2002).

\subsubsection{The Age of the Company and Value Creation}

Some research shows that the firm's age determines board composition (Yeoh \& Jubb, 2001; Yeh \& Woidtke, 2005) and increased agency costs. In this sense, Yeoh and Jubb (2001) show that younger Australian firms require a higher external audit quality. In our Cameroonian context, newly established firms face significant competition that threatens their survival and growth. Therefore, it is expected that young companies require a different quality of external audit, among 
other things, to bring reliable and attractive information to the market, thus contributing to improving their performance and even creating value within the company.

\subsection{Motivation and Literature Gap}

The literature presented above notes that most studies on the relationship between external audit quality and value creation have been conducted in developed countries and much more on listed companies. The results demonstrate the existence of a link between the two concepts. Due to our business environment, we question whether such results can still be verified in our context.

In this paper, we propose to verify the existence of a link between audit quality and value creation in the Cameroonian context. For this reason, in this study, contrary to other works on the subject, we combine both the effect of the two determinants of audit quality (competence and independence) of the audit developed by De Angelo on the creation of value while controlling for the effect of other exogenous factors (the size and age of the company).

\section{Research Methodology}

\subsection{Empirical Validation Process of the Hypotheses on the Relationship between External Audit Quality and Value Creation}

This section is about the general approach of the research starting from the epistemological paradigm, the population of the study, the choice of the sample and the method of data collection, the measurement instrument and the statistical methods used for data processing.

\subsection{The Epistemological Paradigm}

All research raises epistemological questions. The validity criteria of our study are verifiability, confirmability, and refutability. In other words, the explanation or prediction of reality. Given these different reasons, we can say that our research is situated in a positivist paradigm.

\subsection{Sample Selection and Data Collection Method}

We opted for the purposive sampling method, which is a method that allows us to choose the elements of the sample in an exact manner and at the same time guarantee that the criteria required by specific research designs are respected. The choice of this method is motivated by the absence of a sampling frame in the field of auditing with the phenomenon we are studying in Cameroon. Although the sample did not cover a significant portion of the population, we have focused on those specific characteristics of a population of interest to answer the research question and permit us to make generalisations given the hypothetical-deductive nature of this research.

Data collection was done by questionnaire. During the administration phase, 
we distributed 127 questionnaires to public limited companies in Yaounde, Douala and Bafoussam, of which 109 were returned. Of these, 12 were not usable. The response rate of the questionnaires received was $85.82 \%$, which we considered satisfactory, given the length of the questionnaire and especially the context of the study. With a usable response rate of $88.99 \%$, we felt it unnecessary to send out reminders.

Table 1 below provides a summary of the questionnaires administered.

\subsection{Theoretical Model of the Study and Definition of the Variables}

This part of our work aims to show that value creation can be influenced by the quality of the external audit and the control variables (size and age of the company). To this end, we present a structural model that establishes the relationship between the membership of the external audit in the "Big Four", the respect of the steps of the audit process, the offer of other services in addition to the audit of the accounts, the evolution of the audit fees and the creation of the value apprehended by the turnover and the net profit.

$$
\text { VACRE }=\alpha_{0}+\alpha_{i} X_{i}+\varepsilon
$$

where: VACRE: Value Creation; $X_{i}$ : the explanatory variables; $\alpha_{0}$ : the constant term; $\alpha_{i}$, the regression coefficients and $\varepsilon$ the error term.

The full empirical form of the model is:

$$
\begin{aligned}
\text { VACRE }= & \alpha_{0}+\alpha_{1} \text { ACACB }+\alpha_{2} \text { RESTEP }+\alpha_{3} \text { OFSAC } \\
& +\alpha_{4} \text { EVOLHO }+\alpha_{5} \text { TAIL }+\alpha_{6} \text { AGE }+\varepsilon
\end{aligned}
$$

By measuring value creation (VACRE), which is the variable explained in terms of changes in sales and net income, our detailed theoretical model is as follows:

- EVOLTUR (Evolution of turnover)

$$
\begin{aligned}
\text { EVOLTUR }= & \alpha_{0}+\alpha_{1} \text { AMBF }+\alpha_{2} \text { RESTAP }+\alpha_{3} \text { OFSAC } \\
& +\alpha_{4} \text { EVOLAF }+\alpha_{5} \text { SIZE }+\alpha_{6} \text { AGE }+\varepsilon
\end{aligned}
$$

- EVOLNETI (Evolution of net income)

$$
\begin{aligned}
\text { EVOLNETI }= & \alpha_{0}+\alpha_{1} \text { AMBF }+\alpha_{2} \text { RESTAP }+\alpha_{3} \text { OFSAC } \\
& +\alpha_{4} \text { EVOLAF }+\alpha_{5} \text { SIZE }+\alpha_{6} \text { AGE }+\varepsilon
\end{aligned}
$$

Table 1. Summary of distributed questionnaires.

\begin{tabular}{ccc}
\hline Elements & Questionnaires & $\%$ \\
\hline Questionnaires administered & 127 & $100 \%$ \\
Collected Questionnaires & 109 & $85.83 \%$ \\
Unanswered Questionnaires & 18 & $14.17 \%$ \\
Unusable Questionnaires & 12 & $11.01 \%$ \\
Usable questionnaires & $\mathbf{9 7}$ & $\mathbf{8 8 . 9 9 \%}$
\end{tabular}

Source: Authors. 
where: AMBF: Auditor's membership of the "Big Four"; RESTAP: Respect of the steps of the audit process, OFSAC: Offering other services in addition to the audit of accounts; EVOLAF: Evolution of audit fees; SIZE: Size of the company and AGE: Age of the company.

\subsection{Operationalisation of the Study Variables}

In Table 2 below, we operationalise the study variables, by identifying the variable, the measurement indicators, stating the terms and conditions and references.

Table 2 provides a summary of the operationalization of all variables, dependent and independent variables.

Table 2. Operationalisation of the study variables.

\begin{tabular}{|c|c|c|c|c|}
\hline Variables & Measurement indicators & $\begin{array}{l}\text { Type of } \\
\text { Variable }\end{array}$ & Terms and conditions & Reference authors \\
\hline \multicolumn{5}{|c|}{ EXPLAINED VARIABLE: VALUE CREATION } \\
\hline EVOLTUR & $\begin{array}{l}\text { Evolution of turnover } \\
\quad(\text { EVOLTUR })\end{array}$ & Binary & $\begin{array}{l}\text { - " } O \text { " if downward change } \\
\text { - } \quad \text { " } 1 \text { " if upward change }\end{array}$ & $\begin{array}{l}\text { Gompers et al. (2003); } \\
\text { Brown et al. (2010) }\end{array}$ \\
\hline EVOLNETI & $\begin{array}{l}\text { Evolution of net income } \\
\quad(\text { EVOLNETI) }\end{array}$ & Binary & $\begin{array}{l}\text { - " } O " \text { if downward change } \\
\text { - } \quad \text { " } 1 " \text { if upward change }\end{array}$ & $\begin{array}{l}\text { Gompers et al. (2003); } \\
\text { Brown et al. (2010); } \\
\text { Fodil et al. (2007) }\end{array}$ \\
\hline \multicolumn{5}{|c|}{ EXPLANATORY VARIABLE: QUALITY OF THE EXTERNAL AUDIT } \\
\hline $\begin{array}{c}\text { COMPETENCE } \\
\text { OF THE }\end{array}$ & $\begin{array}{l}\text { Membership of the auditor } \\
\text { in the "Big Four" (MABF) }\end{array}$ & Binary & $\begin{array}{l}\text { - “ } O{ }^{\prime} \text { if no } \\
\text { - } \quad \text { “ } 1 \text { ” if yes }\end{array}$ & $\begin{array}{c}\text { Dumontier et al. (2006); } \\
\text { Wafa (2013); } \\
\text { Gana \& Lajmi (2013) }\end{array}$ \\
\hline $\begin{array}{c}\text { EXTERNAL } \\
A U D I T O R\end{array}$ & $\begin{array}{l}\text { Respect of the steps of the } \\
\text { audit process (RESPTAP) }\end{array}$ & Ordinal & $\begin{array}{l}\text { - " } 0 \text { " if never } \\
\text { - “ } 1 \text { " if often } \\
\text { - " } 2 \text { " if always }\end{array}$ & $\begin{array}{l}\text { Djoutsa \& Tagne (2013); } \\
\text { Tseguiankap (2015); } \\
\text { Mock \& Wright (1999) }\end{array}$ \\
\hline $\begin{array}{l}\text { INDEPENDENCE } \\
\text { OF THE }\end{array}$ & $\begin{array}{l}\text { The provision of other } \\
\text { services in addition to the } \\
\text { audit of accounts (OFSAC) }\end{array}$ & Ordinal & $\begin{array}{l}\text { - } \quad \text { “ } 0 \text { ” if never } \\
\text { - “ } 1 \text { " if often } \\
\text { - } \quad \text { " } 2 \text { " if always }\end{array}$ & $\begin{array}{l}\text { Higgs \& Skantz (2006); } \\
\text { Djoutsa \& Tagne (2013) }\end{array}$ \\
\hline $\begin{array}{c}\text { EXTERNAL } \\
A U D I T O R\end{array}$ & $\begin{array}{l}\text { Evolution of audit fees } \\
\text { (EVOLAF) }\end{array}$ & Ordinal & 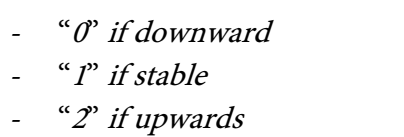 & $\begin{array}{c}\text { Wafa (2013); } \\
\text { Higgs \& Skantz (2006) }\end{array}$ \\
\hline \multicolumn{5}{|c|}{ CONTROL VARIABLES: COMPANY SIZE AND AGE } \\
\hline$S I Z E$ & Size of the company & Metric & Staffing levels & Abbott \& Parker (2000) \\
\hline$A G E$ & Age of the company & Metric & $\begin{array}{l}\text { - } \quad \text { "1" Less than } 3 \text { years old } \\
\text { - } \quad \text { "2" Between } 3 \text { and } 6 \text { years } \\
\text { - } \quad \text { "3" More than } 6 \text { years old }\end{array}$ & Yeoh \& Jubb (2001) \\
\hline
\end{tabular}

Source: Authors. 


\subsection{Method of Statistical Analysis}

- To process and analyse data, we used the SPSS 23 software because of its high scientific scope;

- To carry out descriptive analysis, we used the flat sort (which allows us to know the number of respondents for each response modality);

- And to test our hypotheses, we used the binary logistic regression for the estimation of the variables and obtained the following results.

\section{Results and Discussion}

\subsection{Results of Descriptive Analysis}

The results of the descriptive analysis are shown in Table 3. It shows that the average level of the variables measuring the quality of value creation is 1.18 $((1.14+1.22) / 2)$ and is significantly different from zero (at the $1 \%$ threshold). This average is closer to the maximum value of the value creation index. Furthermore, the examination of the quality of external auditing shows that, on average, $1.55 \%$ of the external auditors of the companies in our sample belong to the "Big Four". On average, $1.87 \%$ of the companies' external auditors in our sample comply with the audit process steps. $2.37 \%$ of them offer other services in addition to the audit of accounts. On average, $2.03 \%$ of the companies in our sample have changed their audit fees. The size and age of the firm appear to vary significantly across all observations, with standard deviations of 1.249 and 1.357.

\subsection{Results of Explanatory Analysis}

\subsubsection{Results of the Bivariate Explanatory Analysis}

It is a question of analysing the chi-square test of independence.

Table 3. Descriptive statistics.

\begin{tabular}{|c|c|c|c|c|c|}
\hline & $\mathrm{N}$ & Minimum & Maximum & Mean & Std. deviation \\
\hline $\begin{array}{l}\text { Membership of the auditor } \\
\text { in the "Big Four" }\end{array}$ & 97 & 1 & 2 & 1.55 & 0.500 \\
\hline $\begin{array}{l}\text { Respect of the steps } \\
\text { of the audit process }\end{array}$ & 97 & 1 & 3 & 1.87 & 0.772 \\
\hline $\begin{array}{l}\text { Provision of other services in } \\
\text { addition to the audit of accounts }\end{array}$ & 97 & 1 & 3 & 2.37 & 0.893 \\
\hline Evolution of audit fees & 97 & 1 & 3 & 2.03 & 0.620 \\
\hline Evolution of turnover & 97 & 1 & 2 & 1.14 & 0.353 \\
\hline Evolution of net income & 97 & 1 & 2 & 1.22 & 0.414 \\
\hline Size of the company & 97 & 1 & 5 & 3.42 & 1.249 \\
\hline Age of the company & 97 & 1 & 5 & 4.05 & 1.357 \\
\hline $\mathrm{N}$ valide & 97 & & & & \\
\hline
\end{tabular}

Source: Authors. 
Table 4 shows that there is a significant dependency between the external audit quality variables (membership of the auditor in the "Big Four" and compliance with the audit process) and the value creation variables (change in turnover and change in profit) as well as the control variable (age of the company). This relationship is significant at the $1 \%$ and $5 \%$ level. The provision of other services and the audit by the external auditor, the evolution of fees, and the size of the company do not significantly influence value creation. Since the chi-square test of independence does not specify the direction of the relationship and does not consider the interrelationships between the variables, logistic regression was used to further refine the descriptive analysis predictions.

\subsubsection{Results of the Multivariate Analysis}

Before proceeding with the multivariate analysis by logistic regression, it is essential to verify the multicollinearity problem between the independent variables.

1) Verification of the Absence of the Multicollinearity Problem Between the Independent Variables

Multivariate analysis is used for the simultaneous treatment of a set of variables (Evrard et al., 2000). In the context of this study, logistic regression requires the absence of a multicollinearity problem between the independent variables introduced in the same model. We verify this condition by using the Pearson correlation test between the explanatory and control variables. The table below presents the correlation matrix between the study's independent variables and the size and age of the firm as control variables.

Examination of the correlation matrix (Table 5) shows that all the correlation coefficients are significantly lower than 0.7 , which is the limit drawn by Kervin (1992). We start to have a severe multicollinearity problem. In this respect, we can conclude that there is no multicollinearity problem.

2) Specification and robustness testing of the study models

Table 4. Chi-square test of Independence.

\begin{tabular}{ccccccc}
\hline & \multicolumn{5}{c}{ VALUE CREATION } \\
\cline { 2 - 7 } Variables & \multicolumn{3}{c}{$\begin{array}{c}\text { Evolution of turnover } \\
\text { (Model 1) }\end{array}$} & \multicolumn{3}{c}{ Evolution of net income } \\
(Model 2)
\end{tabular}

${ }^{* * *},{ }^{* *}$ and ${ }^{*}$ significance at the $10 \%, 5 \%$ and $1 \%$ levels respectively. Source: Authors. 
Table 5. Correlation matrix between the independent variables on ownership structure and the control variables (firm size and age).

\begin{tabular}{ccccccc}
\hline & AMBF & RESPTAP & OFSAC & EVOLAF & EVOLTUR & EVOLNETI \\
\hline AMBF & 1 & & & & & \\
& $0.218^{*}$ & & & & & \\
RESPTAP & 0.032 & 1 & & & & \\
& $-0.272^{* *}$ & -0.123 & & & & \\
OFSAC & 0.007 & 0.228 & 1 & & & \\
& $-0.357^{* *}$ & -0.165 & $0.223^{*}$ & & & \\
EVOLAF & 0.000 & 0.106 & 0.028 & 1 & & \\
& -0.091 & -0.162 & 0.024 & 0.029 & & \\
EVOLTUR & 0.378 & 0.112 & 0.813 & 0.780 & 1 & 1 \\
& -0.033 & -0.137 & -0.054 & 0.039 & $0.730^{* *}$ & \\
EVOLNETI & 0.745 & 0.181 & 0.598 & 0.702 & 0.000 & 1 \\
& & & & & & \\
\hline
\end{tabular}

Source: Authors.

On reading Table 6, we can see that these two models reveal a positive value for the variable representing the unspecified factors (Constant). This value is most significant for both models. Moreover, the Chi-square statistic attesting to the specification of the models is significant at the $10 \%$ threshold in the first model and at the $1 \%$ and $\mathbf{5 \%}$ thresholds for the second model.

The different $\mathrm{R}^{2}$ (Cox and Snell and Nagelkerke) show that the quality of the external audit explains the creation of value in various percentages when measured by the evolution of the turnover and the result. According to $\mathrm{R}^{2}$ of Nagelkerke's, the determinants of audit quality explain only $2.9 \%$ of the value creation when measured by the evolution of turnover. The same variables explain $1.9 \%$ of the value creation when measured by the evolution of the result.

3) Influence of the Quality of the External Audit on Value Creation: Estimation of the Parameters by the "logit" Method

We have previously made some assumptions that need to be tested at this stage. For this purpose, Table 7 below presents the results of the binary logistic regression analysis.

\subsection{Interpretation of Results}

As a reminder, the research problem raised in this article involves finding an answer to the following research question: Does external audit quality influence value creation? In other words, what are the determines audit quality that explain value creation in Cameroonian firms?

To answer the set questions, we conducted a literature review and administered a questionnaire. We then processed the data obtained statistically. It is now time to interpret the results obtained to highlight the answers to our research 
Table 6. Specification and robustness testing of the study models.

\begin{tabular}{|c|c|c|c|c|c|c|c|c|c|c|}
\hline & \multicolumn{5}{|c|}{ Evolution of turnover (Model 1) } & \multicolumn{5}{|c|}{ Evolution of net income (Model 2) } \\
\hline & \multirow[b]{2}{*}{ Chi-Square } & \multirow{2}{*}{$\begin{array}{c}-2- \\
\text { Log de } \\
\text { vraisemblance }\end{array}$} & \multicolumn{2}{|r|}{$\mathrm{R} 2$} & \multirow[b]{2}{*}{ Constante } & \multirow[b]{2}{*}{ Chi-Square } & \multirow{2}{*}{$\begin{array}{c}-2- \\
\text { Log de } \\
\text { vraisemblance }\end{array}$} & \multicolumn{2}{|r|}{$\mathrm{R} 2$} & \multirow[b]{2}{*}{ Constante } \\
\hline & & & $\begin{array}{c}\text { Cox et } \\
\text { Snell }\end{array}$ & Nagelkerke & & & & $\begin{array}{l}\text { Cox et } \\
\text { Snell }\end{array}$ & Nagelkerke & \\
\hline $\mathrm{AMBF}$ & 0.42 & 80.031 & 0.000 & 0.001 & 0.04 & 0.055 & 101.297 & 0.001 & 0.001 & 0.164 \\
\hline RESTAP & 2.11 & 77.963 & 0.022 & 0.038 & 0.001 & 1.49 & 99.863 & 0.015 & 0.024 & 0.003 \\
\hline OFSCA & $0.069^{* * *}$ & 80.03 & 0.001 & 0.001 & 0.02 & 0.113 & 101.239 & 0.001 & 0.002 & 0.037 \\
\hline EVOL4F & 0.541 & 79.532 & 0.006 & 0.01 & 0.017 & $0.02^{\star *}$ & 101.333 & 0.000 & 0.000 & 0.101 \\
\hline TAIL & 0.523 & 79.55 & 0.005 & 0.01 & 0.009 & 0.179 & 101.174 & 0.002 & 0.003 & 0.034 \\
\hline AGE & 0.132 & 79.941 & 0.001 & 0.001 & 0.008 & $0.000^{*}$ & 101.352 & 0.000 & 0.000 & 0.102 \\
\hline
\end{tabular}

${ }^{* * *},{ }^{* *}$ and ${ }^{*}$ significance at the $10 \%, 5 \%$ and $1 \%$ levels respectively. Source: Authors.

Table 7. Logistic regression.

\begin{tabular}{|c|c|c|c|c|c|c|c|c|}
\hline \multirow{3}{*}{ Variables } & \multicolumn{8}{|c|}{ VALUE CREATION } \\
\hline & \multicolumn{4}{|c|}{$\begin{array}{l}\text { Evolution of turnover } \\
\text { (Model 1) }\end{array}$} & \multicolumn{4}{|c|}{$\begin{array}{l}\text { Evolution of net income } \\
(\text { Model } 2)\end{array}$} \\
\hline & $B$ & E. $S$ & Wald & Sig. & $B$ & E. $S$ & Wald & Sig. \\
\hline$A M B F$ & 0.281 & 0.702 & 0.160 & 0.689 & -0.165 & 0.581 & 0.081 & 0.776 \\
\hline RESPTAP & 0.709 & 0.419 & 2.856 & $0.091^{* * *}$ & 0.503 & 0.352 & 2.041 & 0.153 \\
\hline OFSCA & 0.091 & 0.356 & 0.065 & 0.798 & 0.104 & 0.300 & 0.120 & 0.729 \\
\hline$E V O L A F$ & 0.422 & 0.539 & 0.612 & 0.434 & 0.006 & 0.449 & 0.000 & 0.990 \\
\hline$T A I L$ & 0.272 & 0.261 & 1.086 & 0.297 & 0.143 & 0.219 & 0.423 & 0.515 \\
\hline$A G E$ & -0.135 & 0.223 & 0.365 & $0.054^{* * *}$ & -0.040 & 0.192 & 0.043 & 0.836 \\
\hline CONSTANTE & -5.131 & 2.596 & 3.905 & $0.048^{* *}$ & -2.597 & 2.064 & 1.584 & 0.208 \\
\hline Chi square & \multicolumn{4}{|c|}{0.597} & \multicolumn{4}{|c|}{0.880} \\
\hline Log likelihood-2 & \multicolumn{4}{|c|}{75.477} & \multicolumn{4}{|c|}{98.954} \\
\hline $\begin{array}{l}R \text {-square of Cox } \\
\text { and Snell }\end{array}$ & \multicolumn{4}{|c|}{0.046} & \multicolumn{4}{|c|}{0.024} \\
\hline Nagelkerke R Square & \multicolumn{4}{|c|}{0.082} & \multicolumn{4}{|c|}{0.038} \\
\hline
\end{tabular}

${ }^{* *},{ }^{* *}$ and ${ }^{*}$ significance at the $10 \%, 5 \%$ and $1 \%$ levels respectively. Source: Authors.

problem and our contribution to the problem of the quality of external auditing and the creation of value within companies in Cameroon.

\section{Summary of Findings}

Table 8 presents a summary of our results. This section presents the answers to how the quality of the external audit affects the creation of value within companies in Cameroon. 
Table 8. Summary of results.

\begin{tabular}{|c|c|c|c|}
\hline & $\begin{array}{l}\text { Nature of the } \\
\text { intended } \\
\text { relationship }\end{array}$ & $\begin{array}{l}\text { Nature of the } \\
\text { relationship } \\
\text { obtained }\end{array}$ & Conclusion \\
\hline \multicolumn{4}{|c|}{ Research hypothesis } \\
\hline $\begin{array}{l}\text { H1: The external auditor's } \\
\text { membership of the "Big Four" creates } \\
\text { more value within the company, }\end{array}$ & Positive & Positive & Rejected \\
\hline $\begin{array}{l}\text { H2: The respect of the steps of the } \\
\text { audit process by external auditor } \\
\text { contributes significantly and positively } \\
\text { to the creation of value in the company, }\end{array}$ & Positive & Positive & Validated \\
\hline $\begin{array}{l}\text { H3: The provision of other services in } \\
\text { addition to the audit by the external } \\
\text { auditor does not contribute to value } \\
\text { creation within the company, }\end{array}$ & Negative & Positive & Validated \\
\hline $\begin{array}{l}\text { H4: The evolution of audit fees } \\
\text { contributes to the creation of value } \\
\text { in the company, }\end{array}$ & Positive & Positive & Rejected \\
\hline \multicolumn{4}{|c|}{ Control variables } \\
\hline Size of the company (SIZE) & Positive & Positive & Rejected \\
\hline Age of the company ( $A G E)$ & Positive & Negative & Validated \\
\hline
\end{tabular}

Source: Authors.

The summary of the results of the analysis in Table 8 above permits us to provide the following answers:

- The external auditor's membership of the "Big Four" network does not contribute to value creation in Cameroonian firms;

As a reminder, it is the AMBF variable that assesses the membership of the external auditor. Table 5 above shows that the external auditor's membership of the "Big Four" network does not have a significant effect on value creation when measured by changes in turnover and net income (because $\beta=\mathbf{0 . 2 8 1}$ and $\boldsymbol{P}=$ 0.689). This result allows us to refute hypothesis H1: The external auditor's membership in the "Big Four" network creates more value within the company;

The result is a contradiction the predictions of the agency theory and inspired trust, which recommend a significant and positive relationship. It is also contrary to the work of Charreaux and Philippe (1997), Krishnan (2002) and De Angelo (1981b) in the French and American context. It is consistent with the studies of Hartarska (2005) and Alvarez (1997) who find no significant relationship between external audit and firm performance in the American context.

This result leads us to believe that audit quality cannot explain value creation in the Cameroonian context despite the fact that the auditor belongs to the "Big 
Four" network.

- The external auditor's compliance with the steps of the audit process promotes value creation in a company

Table 5 shows a positive and significant association between compliance with the steps of the audit process by the external auditor and the creation of value as measured by the evolution of turnover. In fact, the coefficient associated with the RESTEPA variable has a positive sign $(\beta=0.709)$ and is statistically significant at the $10 \%$ threshold (because $P=0.091$ ). This allows us to confirm our hypothesis H2: The respect of the audit process steps by external auditor contributes significantly and positively to the creation of value in the company. These results are consistent with those of Mock and Wright (1999) and Manita and Chemangui (2007) in the French context. They conclude that the quality of the audit measured by the respect of the audit process steps is significantly linked to the creation of value. This result is based on the agency theory, and as a result, we believe that value creation can be explained in the Cameroonian context by the compliance of the external auditor with the steps of the audit process because compliance with these steps allows the auditor to evaluate the techniques and means of control implemented, compliance with regulations and procedures, which should enable the detection and explanation of existing malfunctions in the company and thus contribute to the success of the company or its performance.

The provision of other services in addition to the audit of accounts by the external auditor does not promote value within the company;

Concerning the offer of other services in addition to the audit of accounts by the external auditor (OFSEAC), the results obtained show that the coefficient associated with this variable is positive and is not statistically significant (because $\boldsymbol{P}=\mathbf{0 . 7 9 8}$ and $\mathbf{0 . 7 2 9}$ ). Thus, we validate hypothesis H3: The external auditor's provision of other services and the audit of accounts does not contribute to the creation of value within the company.

This result is consistent with the stakeholder theory and the work of Goldman and Barlev (1974) in the American context, which supports the hypothesis that when the independence of the auditor is compromised, the latter does not contribute to the creation of value because the external auditor is in a position to satisfy his interests to the benefit of other stakeholders.

Therefore, we conclude that in our context, the provision of other services truncates the independence of the external auditor and the audit of the accounts; these do not appear to have a significant impact on value creation in our context.

\section{- Evolution of audit fees does not promote value creation}

Table 5 shows a positive and insignificant association between the evolution of audit fees and value creation. In fact, the coefficient associated with the EVOLAF variable has a positive sign $(\beta=0.422$ and 0.06$)$ in both models and is not statistically significant (as $P=0.434$ and 0.990 ). This allows us to refute our hypothesis H4: The evolution of audit fees contributes to creating value within the company. 
This result contradicts the predictions of the stakeholder theory and theory of inspired trust. It contradicts Moutinho et al.'s (2012) and Stanley (2011) results in a US context.

This result teaches us that increasing audit fees does not guarantee that the audit work will be of high quality. The question remains whether a downward trend will not contribute to the destruction of value.

\section{- Firm size does not explain value creation in Cameroonian firms}

As a reminder, the variable SIZE measures the firm's size as measured here by the number of employees. Table 5 above shows that firm size does not significantly affect value creation when measured by changes in sales and net income (because $\boldsymbol{\beta}=\mathbf{0 . 2 7 2}$ and $0.143 ; \boldsymbol{P}=\mathbf{0 . 2 9 7}$ and $\mathbf{0 . 5 1 5}$ ). This result contradicts the results of Beasley and Petroni (2001), Carcello et al. (2002) in the American context and matches those of Abdullahi, Norfadzilah, Umar and Lateef Saheed Ademola (2020) in the Nigerian context. It suggests that in the Cameroonian context, firm size is not a determinant of firm performance.

\section{- The age of the firm explains the creation of value in Cameroonian firms}

From the table above, we see that the firm's age contributes strongly to value creation in Cameroonian firms when the evolution of sales measures it (because $\beta=-0.135$ and $P=0.05$ ). This result is based on the agency theory and follows Yeoh and Jubb (2001) in the Australian context. It is contrary to those of Abdullahi, Norfadzilah, Umar and Lateef Saheed Ademola (2020) in the Nigerian context. This result shows that the larger the company, the more its turnover will evolve, given the reputation it has already acquired in the market.

\section{Conclusion}

In this paper, we sought to shed some light on the effect that the quality of external auditing can have on the creation of value in Cameroonian companies. To achieve our goals, we first established the theoretical basis of our concepts and then formulated the research hypotheses mentioned above. Once these hypotheses were formulated, we screened them through empirical verification, which is how we constituted a final sample by means of a questionnaire intended to collect information on 97 companies, i.e., 62 in the city of Douala, 29 in the city of Yaoundé, and 6 in the city of Bafoussam over a period of 5 years (2015-2020). We then used the SPSS 23 software to process the data through Chi-square tests of independence and the estimation of the different parameters of our research model through binary logistic regression. Table 6 summarises the results obtained in our study. These results reveal the absence of a significant link between the quality of the external audit as measured by (the external auditor's membership of the "Big Four", the provision of other services in addition to the audit of accounts, the evolution of audit fees) and the creation of value as measured by the evolution of turnover and net income (rejection of hypotheses $\mathrm{H} 1$ and H4; validation of hypothesis $\mathrm{H} 3$ ). The respect of the steps of the audit process by the external auditor has a significant influence on the creation of value in terms of 
the evolution of turnover (Validation of hypothesis H2). With regard to the control variables, the size of the company does not explain the value creation of companies in the Cameroonian context. However, the age of the firm does explain its value creation in terms of turnover.

This paper thus contributes to the debate on demand for quality auditing and value creation, using a composite measure of the quality index that captures both the determinants of competence and the auditor's independence.

\subsection{Recommendations of the Study}

Considering the findings of this study, the following measures are hereby recommended for public limited companies in Cameroon as a means of enhancing audit quality and, ultimately, value creation. Management of public limited companies in Cameroun can improve the value creation of their companies by hiring the service of a competent auditor who respects the steps of the audit process because the compliance with these steps allows the auditor to evaluate the techniques and means of control implemented, compliance with regulations and procedures, which should allow the detection and explanation of existing malfunctions of the company and thus contribute to the success of the company, its performance or value creation.

\subsection{Limitations of the Study}

This work has some limitations, first of all, the method of data collection. As the data used in this study is from a primary source, i.e. collected by questionnaire in the field, there is the possibility of numerous biases. The answers obtained from these questionnaires do not always reflect the realities of the phenomenon studied. The sample size can also be considered a limitation, as it was only made up of 97 public limited companies that were willing to provide complete information for this research. The study was carried out in Douala, Yaoundé, and Bafoussam, where most Cameroonian companies are concentrated. However, the harvest was meagre despite all the resources mobilised. The results obtained are difficult to generalise because they only take into account unlisted companies. Another limitation that needs to be clarified concerns the variables in the study. First, we would have had to expand the study to include other external audit quality variables such as co-auditing, adherence to the audit timetable, and the time allotted for audit assignments. In addition, this research deserves to be treated as a longitudinal study to make the results more robust. Finally, the measures of audit quality used in this study are only simplifications and may not give an accurate picture of actual audit quality. In view of these shortcomings, it is necessary to consider adopting another more interesting measure based on the evaluation of audit programmes, i.e., the adaptation of the audit methodology to the company's risk areas (Pigé \& Chemangui, 2004).

\subsection{Perspective of the Study}

Because the field of research on external audit quality and value creation is so 
broad, it has proven tedious to analyse all of the related variables in a single study. Researchers could survey the influence of other variables characteristic of external audit quality (co-auditing, adherence to the audit timetable, and the time allowed for audit assignments) and value creation (Accounting rates of return, Equity per share, Earnings per share etc.) while controlling for the effect of other exogenous variables (geographic dispersion) on value creation to improve the quality of this work.

\section{Conflicts of Interest}

The authors declare no conflicts of interest regarding the publication of this paper.

\section{References}

Abbott, L. J., \& Parker, S. (2000). Audit Committee Characteristics and Auditor Selection. Journal of Practice \& Theory, 19, 47-66. https://doi.org/10.2308/aud.2000.19.2.47

Abdullahi, N. U., \& Lateef, S. A. (2020). The Impact of Audit Quality on the Financial Performance of Listed Companies Nigeria. Journal of Critical Reviews, 7, 37-42.

Alvarez (1997). Audit and Firm Performance in South America. Journal of Economic and Finance, 18, 57-124.

Anderson, E. W., Fornell, C., \& Mazvancheryl, S.K. (2004). Customer Satisfaction and Share Holder Value. Journal of Marketing, 68, 172-185.

https://doi.org/10.1509/jmkg.68.4.172.42723

Beasley. M. S., \& Petroni, K. R. (2001). Board Independence and Audit Firm Type. Journal of Practice \& Theory, 20, 97-114. https://doi.org/10.2308/aud.2001.20.1.97

Belkaoui, A. R. (1994). Organizational and Budgetary Slack (p. 124). Greenwood Publishing Group.

Bliss, M. A., Gul, F. A., \& Majid, A. (2011). Do Political Connections Affect the Role of Independent Audit Committees and CEO Duality? Some Evidence from Malaysian Audit Pricing. Journal of Conptemporary Accounting and Economics, 7, 82-98. https://doi.org/10.1016/j.jcae.2011.10.002

Brown, K., Burgess, J., Festing, M., \& Royer, S. (Eds.) (2010). Value Adding Webs and Clusters-Concepts and Cases, München and Mering. Rainer HamppVerlag.

Caby, J., \& Hirigoyen, G. (2001). La Création de Value de l'Entreprise (2nd ed., p. 204). Economica.

Cappelletti, L., \& Khouatra, D. (2011). La Mesure De La Creation De Valeur Organisationnelle: Le Cas D'uneentreprise Du Secteur De La Gestion De Patrimoine. Hall.

Carcello, J. V., Hermanson D. R., Neal, T. L., \& Riley, R. A. (2002). Board Characteristics and Audit Fees. Contemporary Accounting Research, 19, 365-384.

https://doi.org/10.1506/CHWK-GMQ0-MLKE-K03V

Carmichael, D. R. (2004). The PCAOB and the Social Responsibility of the Independent Auditor. Accounting Horizons, 18, 127-133. https://doi.org/10.2308/acch.2004.18.2.127

Charreaux, G., \& Philippe, D. (1997). Point sur le gouvernement des entreprises. Revue Banque \& Marchés, No. 29, 28-34.

Chevallier, J. (2003). La gouvernance, un nouveau paradigmeétatique? Revue françaised' administrationpublique, No. 105-106, 203-217.

https://doi.org/10.3917/rfap.105.0203 
Collins, J. C., \& Porras, J. I. (1994). Built to Last: Successful Habits of Visionary Companies. Harper Business.

De Angelo, L. E (1981a). Auditor Size and Audit Quality. Journal of Accounting and Economics, 3, 183-199. https://doi.org/10.1016/0165-4101(81)90002-1

De Angelo, L. E. (1981b). Auditor Independence, Low Bailing, and Disclosure Regulation. Journal of Accounting and Economics, 3, 113-127. https://doi.org/10.1016/0165-4101(81)90009-4

Djongoue, G. (2007). Fiabilité de l'information comptable et gouvernance d'entreprise: une analyse de l'audit légal dans les entreprises Camerounaises. Communication au Colloque international sur la gouvernance: Quelles pratiques pour promouvoir le développement économique de P Afrique. Lille, novembre 2007 Economics, June.

Djoutsa, W. L., \& Tagne, F. A. (2013). Le comportement des auditésqueleffet sur la qualité des Services rendue par les Cabinets d'Audit au Cameroun? Gestion et Organisation, 6, 93-103. https://doi.org/10.1016/j.rgo.2014.09.002

Dumontier, P., Chtourou, S., \& Ayedi, S. (2006). La qualité de l'audit externe et les mécanismes de gouvernance des entreprises: Une étude empirique menée dans le contexte tunisien. Association francophone de la comptabilité, Tunis 2006.

Evrard, Y., Pras, B., \& Roux, E. (2000). Market: Etudes et recherchesen marketing. Dunod.

Flint, D. (1988). Philosophy and Principles of Auditing. Macmillan.

Fodil, A., Chokri, M., \& Fatma, S. (2007). La réputation de l'audit externe et les mécanismes de gouvernement d'entreprise: Interactions et effet sur la performance. "COMPTABILITE ET ENVIRONNEMENT”, France. CD-Rom. ffhalshs-00544896

Freeman (1984). La théorie des parties prenantesen question. Master, France. 2017. Officel-01432945f.

Gana, M. R., \& Lajmi, A. L. (2013). Structure de propriété et qualité de l'auditexterne: Cas des entreprisesbelgescotées. Gestion 2000, 29, 83-96.

https://doi.org/10.3917/g2000.293.0083

Goldman, A., \& Barlev, B. (1974). The Auditor-Firm Conflict of Interest: Its Implication for Independence. The Accounting Review, 49, 707-718.

Gompers, P. A., Ishii, J. L., \& Metrick, A. (2003). Corporate Governance and Equity Prices. Quarterly Journal of Economics, 118, 107-156.

https://ssrn.com/abstract $=278920$

https://doi.org/10.1162/00335530360535162

Hartarska, V. (2005). Governance and Performance of Microfinance Organizations in Central and Eastern Europe and the Newly Independent States. William Davidson Institute Working Paper Number 677, World Development, 33, 1627-1643.

Hassan, S. U., \& Farouk, M. A. (2014). Audit Quality and Financial Performance of Quoted Cement Firms in Nigeria. European Journal of Business and Management, 6, 73-82.

Heil, D. (2012). The Influence of the Auditor on the Earnings Quality of Their Clients. Master's Thesis Accounting Auditing \& Control, Eramus University Rotterdam.

Higgs, J. L., \& Skantz, T. (2006). Audit and Nonaudit Fees and the Market's Reaction to Earnings Announcements. Journal of Practice \& Theory, 25, 1-26.

https://doi.org/10.2308/aud.2006.25.1.1

Jensen, M. C., \& Meckling, W. H. (1976). Theory of the Firm: Managerial Behavior, Agency Costs and Ownership Structure. Journal of Financial Economics, 3, 305-360.

https://doi.org/10.1016/0304-405X(76)90026-X

Kervin, J. B. (1992). Methods for Business Research. Harper Collins Publishers.

Krishnan, G. V. (2002). Audit Quality and the Pricing of Discretionary Accruals. Documents 
de travail. http://papers.SSRN.com

https://doi.org/10.2139/ssrn.320164

Limperg, T., Flint, D., \& Bak, G. G. M. (1985). The Social Responsibility of the Auditor: A Basic Theory on the Auditor's Function. Limperg Institute.

Louise, F. (2005). Conference sur la gouvernanceorganisé par l'ONU. Fevrier 2005

Manita, R., \& Chemangui, M. (2007). Les approches d'évaluation et les indicateurs de mesure de la qualité d'audit: Une revue critique. In Actes du 28ème Congrès de P Association francophone de Comptabilité.

Mock, T. J., \& Wright, A. M. (1999) Are Audit Program Plans Risk-Adjusted? Auditing: A Journal of Practice and Theory, 18, 55-74. https://doi.org/10.2308/aud.1999.18.1.55

Moore, G., \& Ronen, J. (1990). External Audit and Asymetric Information. Auditing: A Journal of Practice and Theory, 9, 234-242.

Moutinho, V., Cerqueira, A., \& Brandao, E. (2012). Audit Fees and Firm Performance. https://doi.org/10.2139/ssrn.2180020

Mustapha, U. A., Mohd Rashid, N. N., Lateef, S. A., \& Bala, A. A. (2019). The Effect of Corporate Governance Attributes on Audit Quality in Nigeria. International Journal of Recent Technology and Engineering (IJRTE), 8, 4882-4886.

https://doi.org/10.35940/ijrte.D8313.118419

Pigé, B., \& Chemangui, M. (2004). La qualité de l'audit: Analyse critique et proposition d'une approche d'évaluation axée sur la nature des travaux d'audit réalisés. In 25ème Congrès de l'Association Francophone de Comptabilité (pp. 1-20).

Poisson, M. (1989). L'AUDIT: Un outil de progrès au service du secteur public. La Revue Administrative, 42, 370-377. http://www.jstor.org/stable/40782503.

Porter, M. (1980). Competitive Strategy. Free Press.

Sarens, G., \& Abdolmohammadi, M. J. (2007). Monitoring Effects of the Internal Audit Function: Agency Theory versus Other Explanatory Variables. International Journal of Auditing, 15, 1-20. https://doi.org/10.1111/j.1099-1123.2010.00419.x

Stanley, J. D. (2011). Is the Audit Fee Disclosure a Leading Indicator of Clients' Business Risk? Auditing: A Journal of Practice \& Theory, 30, 157-179.

https://doi.org/10.2308/ajpt-10049

Sundaram, A. K., \& Inkpen, A. C. (2004). The Corporate Objective Revisited. Organization Science, 15, 350-363. https://doi.org/10.1287/orsc. 1040.0068

Tseguiankap, B. (2015). Les déterminants de la compétence du commissaire aux comptes et respect du processus d'audit. Thèsede master, Universitéde Dschang.

Wafa, M. A. (2013). Mécanismes de gouvernance et qualité de l'audit externe: Le cas français. Revue Gestion et Organisation, 5, 183-195.

https://doi.org/10.1016/j.rgo.2013.12.012

Watts, R. L., \& Zimmerman, J. L (1986). Positive Accounting Theory. Prentice-Hall, Contemporary Topics in Accounting Series Englewood Cliffs.

Yeh, Y.-H., \& Woidtke, T. (2005). Commitment or Entrenchment? Controlling Shareholders and Board Composition. Journal of Banking \& Finance, 29, 1857-1885. https://doi.org/10.1016/j.jbankfin.2004.07.004

Yeoh, E., \& Jubb, C. (2001). Governance and Audit Quality: Is There an Association (50 p.)? University of Melbourne, Department of Accounting.

Zafar, I. (2002). OIC and the Kashmir Issue: Options for India. International Studies, 39, 191-194. https://doi.org/10.1177/002088170203900205 